\title{
Differences in Students Mathematical Problem Solving Ability Given Guided Discovery Learning and Cooperative Learning STAD-Type
}

\author{
Nova Yanti Sinaga \\ Post Graduate Mathematics Education \\ State University of Medan \\ Medan, Indonesia \\ Corresponding email: novaysinaga@gmail.com
}

\author{
Mukhtar \\ Faculty of Mathematics Education \\ State University of Medan \\ Medan, Indonesia
}

\author{
Syafari \\ Faculty of Mathematics Education \\ State University of Medan \\ Medan, Indonesia
}

\begin{abstract}
Problem solving is a basic activity for human beings and becomes one of the goals in learning mathematics. The goal can not be fulfilled if the classroom learning does not pay attention to the problem solving ability. Guided discovery learning and cooperative learning STAD-type can be used to meet the goal through the learning process. The purpose of this study was to find out: First, the differences in mathematical problem solving ability of students who are given guided discovery learning and cooperative learning STAD-type, and the second is interactions between learning models (guided discovery learning and cooperative learning STAD-type) with students gender on mathematical problem solving ability. The population in this study was all eighth grade students of SMP Negeri 13 Medan academic year 2018/2019. The sample was taken randomly in two selected classes which were class VIII-1 as experimental class-1 and class VIII-2 as experimental class-2, each amounting to 32 students. The research instrument used was a test of problem solving ability. Data was analyzed with twoway Anova. The results of this study show that (1) There is difference in mathematical problem solving ability between students who are given with guided discovery learning and those who are given with cooperative learning STAD-type, (2) There is interaction between learning models (guided discovery learning and cooperative learning STAD-type) with students gender on students mathematical problem solving ability.
\end{abstract}

Keywords-mathematical problem solving ability; guided discovery learning; cooperative learning STAD-type

\section{INTRODUCTION}

Nowadays, science is developing very rapidly and increasingly touching aspects of human life. Mastery of science and technology depends on education and teaching in schools that will produce human resources who can master the science and technology. Mathematics, as the Queen of Sciences, is one of the subjects that can make this happen.
Mathematics is aware of its important role. The importance of mathematics, based on the ability of mathematical students is the foundation which is an absolute requirement that must be mastered to be able to train students to think clearly, logically, systematically, and have personality and skills to solve problems in everyday life. Mathematics needs to be taught to students because (1) it is always used in all aspects of life; (2) all fields of study require appropriate mathematical skills; (3) is a means of communication that is strong, concise, and clear; (4) can be used to present information in various ways; (5) improve the ability of logical thinking, accuracy, and spatial awareness; and (6) giving satisfaction to efforts to solve problems [1]

It is known from the results of the evaluation of the Trends in Mathematics and Science Study (TIMSS) in the 2015 TIMSS survey, the average score of Indonesian students' mathematics achievement was still significantly below the TIMSS average of 500. Indonesia was ranked 45 th out of 50 evaluated countries with a score of 397 [2]. This condition is also similar to the results of the 2015 PISA survey. The results showed that the performance of Indonesian students in the field of mathematics was still relatively low. The average score of achievement of Indonesian students for mathematics is ranked 63 out of 69 evaluated countries. The average OECD country score was 490 , while the Indonesian score was 386 [3]. This shows that Indonesian mathematics achievement is still relatively low. Looking at the situation, the average score of achievement of Indonesian students in the field of mathematics is indeed worrying.

From the unsatisfactory facts above, one of the contributing factors is students' problem solving ability that are classified as low. Problem solving is the main focus of the mathematics curriculum that shows that one of the abilities that students must possess in mathematics learning is problem 
solving ability [4]. In implementing mathematics learning in schools, teachers must pay attention to five mathematical abilities, there are: connections, reasoning, communication, problem solving, and representations [5].

Problem solving ability becomes one of the goals in learning mathematics in schools because it trains the way of thinking and reasoning in drawing conclusions, developing problem solving skills, and developing the ability to convey information or communicate ideas through oral, written, pictures, graphics, maps, diagrams, and so on [6]. Then according to [7], problem solving is one of the most important forms of learning in mathematics. Through problem solving students can practice and integrate concepts, theorems and skills that have been learned. Furthermore, he also said that teaching students to solve problems allows students to be more analytical in making decisions in life.

There are several factors that are the causes of students' low mathematical problem solving ability. One of the things that can be seen from mathematics learning in schools is the learning models that relies more on lectures. It makes mathematics teaching is unattractive, students tend to be passive, there is no students want to ask questions, and students are unable to solve the practice questions given by the teacher and students are not interested in learning mathematics which ultimately results in students' performances of mathematics becomes relatively low. According to [8], the decline in mathematical understanding of students in the class is partly because (a) in teaching the teacher often exemplifies students how to solve problems, (b) students learn by listening and imitating the teacher to do mathematics, then the teacher solves it himself and (c) when teaching mathematics, the teacher immediately explains the topic to be studied, followed by giving examples, and for training. Students are not much involved in constructing their knowledge, only accepting the information conveyed from the teacher. Students are not able to answer questions that are different from the example given by the teacher. This is because students only hear the teacher's explanation, imitate, and do the exercises following the pattern given by the teacher, not because students understand the concept.

The learning model that can be used to improve students' mathematical problem solving skills is a guided discovery learning model and cooperative learning STAD-type. Some previous researches have shown the positive impact of implementing guided discovery learning and cooperative learning STAD-type in problem solving. The research on guided discovery as in [9] showed that guided discovery models were effectively used to improve students' mathematical problem solving ability. The result of the research in [10] showed that the STAD cooperative learning model was useful in increasing students' achievement in mathematics and problem solving ability.

\section{THEORETICAL FRAMEWORK}

\section{A. Guided Discovery (GD)}

Discovery learning is a learning model developed based on constructivism. That discovery is not a learning model that is carried out to find something truly new, but in this model students are expected to find their knowledge actively such as by doing guesses, estimates, and experiments so students can find concepts, formulas, etc. that will be used in learning. Some opinions about discovery learning, namely as in [11] stated a discovery model is a learning model that is arranged in such a way that the children acquire knowledge that they did not know beforehand through notification, either partially or completely. Meanwhile, Bruner in [12] stated that discovery learning occurs when individuals have to use the process of thought to find out the meaningfulness of something themselves.

In applying the discovery learning model, the teacher must be able to guide and direct student learning activities in accordance with the objectives. This condition is what is called guided discovery. The guided discovery model indicates that the teacher guides students and students are encouraged to think for themselves so they can find general principles based on the directions or questions given by the teacher. The advantages of discovery learning as stated in [13] shows that: First, knowledge is long-lasting or longremembered or easier to remember when compared to knowledge learned in other ways; second, the learning outcomes of the discovery have better transfer effects than other learning outcomes; third, thoroughly learning discovery enhances student reasoning and the ability to think freely. From the description above, it was concluded that guided discovery learning would activate students in learning and equip students with longer-lived knowledge because faced with meaningful learning, then would be able to apply the new knowledge to problem solving.

The characteristics of guided discovery can be more clearly seen from the six principles as follows: a) children learn by being actively engaged in and reflecting on an experience, $b$ ) children learn by building on what they already know, c) children develop higher order thinking through guidance at critical points in the learning process, d) children have different ways and modes of learning, e) children learn through social interaction with others, f) children learn through instruction and experience in accord with their cognitive development [14].

Guided discovery learning steps used in this study are: (1) giving of problem and stimulus, (2) problem statement, (3) data collecting, (4) data processing, (5) verification, and (6) generalization [15]

\section{B. Cooperative Learning STAD-type (STAD)}

Cooperative learning is learning that emphasizes and encourages cooperation between students in learning something. According to [16], Student Teams Achievement Division (STAD) is one type of cooperative learning developed by Slavin and is one type of cooperative that emphasizes the existence of activities and interactions between students to motivate each other and help each other in mastering subject matter in order to achieve maximum achievement.

STAD has five important elements that must be set, there are: (1) positive interdependence, the success of a group depends on the efforts of each member; (2) individual 
responsibility, the key to the success of group work methods is the preparation of teachers in the preparation of students' duties; (3) face to face, this interaction activity will provide learners to form synergies that benefit all members. The results of the thoughts of some heads will be richer than the thoughts of one head; (4) communication between members, the success of a group also depends on the willingness of its members to listen to each other and their abilities to express their opinions; (5) evaluation of group processes, teachers need to schedule specific times for groups to evaluate the group work process and the results of their collaboration so that they can work together more effectively.

The steps of cooperative learning STAD-type are: (1) delivering goals and motivating students, (2) presenting/ delivering information, (3) organizing students in study groups, (4) guiding groups working and learning, (5) evaluating, (6) giving awards [17].

\section{Mathematical Problem Solving Ability (MPSA)}

In learning mathematics, a problem is a question / task that students cannot directly solve. A task is said to be problem if the solving demands that the solver must connect his/her earlier knowledge in a new way. If he/she can immediately recognize the procedure needed for solving the task, it is for $\mathrm{him} /$ her a routine task (or standard task or exercise) [18]. Not all questions are a problem for a student but can be a problem for another student. The problem must be "challenge" and an unknown routine procedure.

In mathematics learning, the problem means that the situation must be solved by requiring deep thinking, reasoning, and linking the knowledge that has been gained to the problem. Problem solving is the means by which an individual uses previously acquired knowledge, skills, and understanding to satisfy the demands of an unfamiliar situation [19]. Similar opinion was also expressed as in [20] that mathematical problem solving ability are the ability to overcome mathematical difficulties by combining mathematical concepts and rules that have been obtained previously to achieve the desired goals.

Problem solving is an important part of mathematics, because in the process of learning, students are possible to use the knowledge of skills that they already have to apply in problem solving. Teaching students to solve problems allows students to be more analytical in making decisions in real life.

Some indicators of mathematical problem solving ability by Polya are as follows: (1) understanding the problem, (2) devising a plan, (3) carrying out the plan, (4) looking back [21]. In this research, the indicator that used to examine problem solving ability are: (1) understanding problem; (2) planning a solution; (3) getting an answer as in [22].

\section{RESEARCH QUESTION}

The following research questions were formulated to guide this study:

1. Is there any difference in mathematical problem solving ability between students who taught with guided discovery learning and cooperative learning STAD-type?
2. Is there any interaction between learning models with gender on students' mathematical problem solving ability?

\section{RESEARCH METHOD}

\section{A. Research Design}

This study was designed as follows:

TABLE I. RESEARH DESIGN

\begin{tabular}{|c|c|c|}
\hline Class & Treatment & Post-test \\
\hline Experimental-1 & $\mathrm{X}_{1}$ & $\mathrm{O}$ \\
\hline Experimental-2 & $\mathrm{X}_{2}$ & $\mathrm{O}$ \\
\hline
\end{tabular}

The posttest (MPSA test $(\mathrm{O})$ ) was administered to examine the treatment effect after experimental class-1 received GD learning $\left(\mathrm{X}_{1}\right)$ and experimental class-2 received STAD learning $\left(\mathrm{X}_{2}\right)$.

\section{B. Participants}

This study was carried out at SMP Negeri 13 Medan. The population in this study were all VIII grade students of SMP Negeri 13 Medan and two classes were randomly selected and randomly assigned as experimental class-1(32 students in VIII-1 class) and experimental class-2 (32 students in VIII-2 class). The experimental-1 class in this study will be giving a guided discovery learning model, and the experimental-2 class will be giving a cooperative learning STAD-type. The participants were not further randomly assigned to treatment conditions as this, according to the authority of the school, could disrupt normal classes. Nonetheless, the sample was assumed to bear similar characteristics in academic ability, regional or ethnic groups.

\section{DATA ANALYSIS, RESUlt, AND DISCUSSION}

The main purpose of this study is to determine the differences in MPSA of students who get GD learning and students who get STAD learning. Furthermore, it will be seen whether there is an interaction between learning model and gender on students' MPSA.

\section{A. Data Description}

The description of the post test of students' MPSA is shown in Table II.

TABLE II. DESCRIPTION OF POSTTEST MPSA

\begin{tabular}{|c|c|c|c|c|c|c|}
\hline Class & $\begin{array}{c}\text { Maximum } \\
\text { Score }\end{array}$ & $\mathbf{N}$ & $\mathbf{X}_{\min }$ & $\mathbf{X}_{\max }$ & $\overline{\boldsymbol{X}}$ & SD \\
\hline Experimental-1 & 100 & 32 & 55 & 97.5 & 77.50 & 12.68 \\
\hline Experimental-2 & 100 & 32 & 50 & 95 & 70.70 & 14.31 \\
\hline
\end{tabular}

From Table II, it can be seen that the average score of the students' post-test MPSA of the experimental class- 1 and the experimental class-2 is different. The average of post-test for the experimental class- 1 is 77.50 while the average value of the post-test for the experimental class- 2 is 70.70 . For more details, presented a diagram of the average value of post-test MPSA of each experimental class can be seen in Fig 1. 


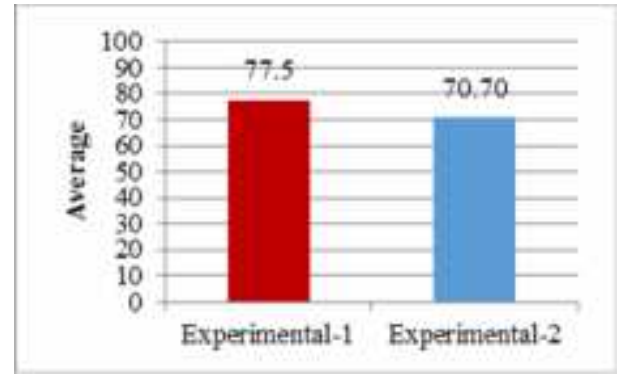

Fig. 1. Post-test Average Score of Students' MPSA

Based on Table II and Fig.1, it can be seen that average score of MPSA post-test of the experimental class-1 that given GD learning is higher than the average experimental class-2 MPSA that given STAD learning.

The data description of students' MPSA post-test grouped by gender can be seen in Table III.

TABLE III. Description OF Post-Test MATHEMATICAL ProbLEM SOlVing ABILITY BASED ON GENDER

\begin{tabular}{|c|c|c|c|c|}
\hline \multirow{2}{*}{ Gender } & \multirow{2}{*}{ Statistic } & \multicolumn{2}{|c|}{ Class } & \multirow{2}{*}{$\begin{array}{c}\text { Marginal } \\
\text { Average }\end{array}$} \\
\cline { 2 - 5 } & & Experimental-1 & Experimental-2 & \\
\hline \multirow{3}{*}{ Male } & $\mathrm{N}$ & 15 & 15 & 68.50 \\
\cline { 2 - 5 } & Mean & 76.50 & 60.50 & \\
\cline { 2 - 5 } & $\mathrm{SD}$ & 11.91 & 10.69 & 79.04 \\
\hline \multirow{3}{*}{ Female } & $\mathrm{N}$ & 17 & 17 & \\
\cline { 2 - 5 } & Mean & 78.38 & 79.71 & 74.102 \\
\cline { 2 - 5 } & $\mathrm{SD}$ & 13.63 & 10.64 & \\
\hline \multicolumn{2}{|c|}{ Marginal Average } & 77.500 & 70.703 & \\
\hline
\end{tabular}

Based on Table III, it can be seen that in the experimental class-1, the average post-test scores of MPSA for 15 male students were 76.50 and for 17 female students were 78.38 . While in the experimental class-2, the average score of MPSA post-test for 15 male students was 60.50 and 17 for female students were 79.71. To be clearer, it is presented a diagram of MPSA post-test for the two experimental classes in Fig. 2.

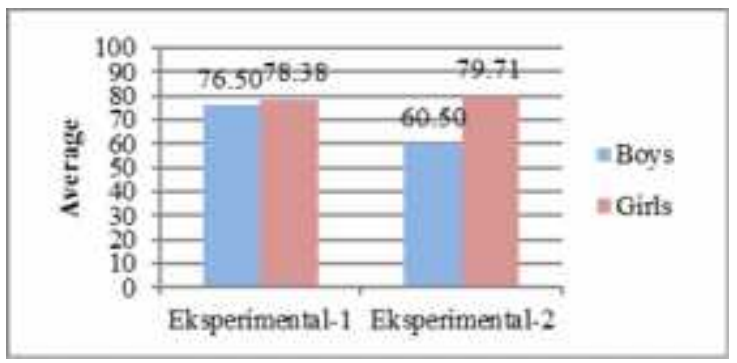

Fig. 2. Post-test Average Score of Students' MPSA by Gender

Based on Table III and Fig. 2, it can be seen that in the experimental class-1 and experimental class-2, the average score of MPSA of male students was lower than female.

\section{B. Data Analysis}

Data analysis of post-test students' MPSA is intended to test hypotheses, as follows: (1) There is difference in MPSA of students who get GD learning model and students who get
STAD learning, (2) There is interaction between learning models with gender on students' MPSA.

Hypotheses testing was done using two-way Anova. Previous prerequisite tests have been carried out, as follows homogeneity test and normality test and both experimental classes have met the requirements of normal distribution and both classes have the same variance. The result of Anova two ways is described in Table IV.

TABLE IV. CALCULATION RESUltS OF Two-WAY ANOVA OF STUDENT MPSA POST-TEST

\begin{tabular}{|c|c|c|c|c|c|}
\hline Source & $\begin{array}{c}\text { Sum } \\
\text { Squares }\end{array}$ & Df & $\begin{array}{c}\text { Mean } \\
\text { Square }\end{array}$ & F & $\begin{array}{c}\mathbf{F}_{\text {table }} \\
(\alpha=\mathbf{0 . 0 5})\end{array}$ \\
\hline Learning (A) & 739.160 & 1 & 739.160 & 5.297 & 5.286 \\
\hline Gender (B) & 1771.906 & 1 & 1771.906 & 12.698 & 5.286 \\
\hline $\begin{array}{c}\text { Learning* } \\
\text { Gender (AB) }\end{array}$ & 1195.729 & 1 & 1195.729 & 8.569 & 5.286 \\
\hline Error & 8372.794 & 60 & 139.546 & & \\
\hline Total & 12079.589 & 63 & & & \\
\hline
\end{tabular}

Based on Table IV, learning models factor (A) obtained the value of $F(A)$ is 5.297. Because $F(A)$ is greater than the $\mathrm{F}_{\text {table }}$ which is $5.297>5.286$ then $\mathrm{H}_{0}$ is rejected. It shows that there is a significant difference between MPSA of students who get GD learning and students who get STAD learning.

Based on Table IV, for the calculation of interaction between learning and gender models it was found that the value of $\mathrm{F}(\mathrm{AB})$ was 8.569 . Because $\mathrm{F}(\mathrm{AB})$ is greater than the

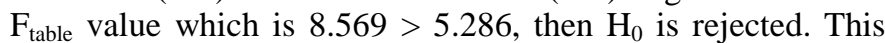
means that there is an interaction between the learning models with gender on students' MPSA. Graphically, the interaction between the learning models and gender can be seen in Fig. 3.

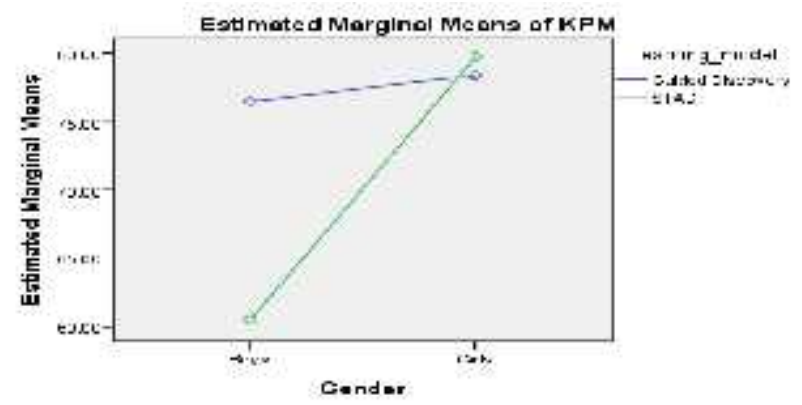

Fig. 3. Graph of Interactions between Learning Models and Gender on MPSA

It can be seen in Fig. 3 that the line of the GD learning model is not parallel and intersects with the line of STAD learning, which means that there is a suspected interaction effect. Thus it can be concluded that there is an interaction effect between the learning models (GD and STAD) and on students' MPSA.

From the two-way Anova test result, it was found that there were significant differences between the learning models and interactions between the learning model and gender, then further tests were carried out. Further tests were carried out using the Scheffe method, namely comparison between lines, between columns, and between cells. Average of MPSA of each cell data can be seen in Table $\mathrm{V}$ and the summary of Scheffe' test result can be seen in Table VI. 
TABLE V. Average of Each Cell Post-test Data Students’' MPSA

\begin{tabular}{|c|c|c|c|}
\hline \multirow{2}{*}{ Gender } & \multicolumn{2}{|c|}{ Learning Model } & $\begin{array}{c}\text { Marginal } \\
\text { Average }\end{array}$ \\
\cline { 2 - 4 } & GD & STAD & $\bar{x}_{1}=68.500$ \\
\hline Male & $\bar{x}_{11}=76.500$ & $\bar{x}_{12}=60.500$ & $\bar{x}_{2}=79.044$ \\
\hline Female & $\bar{x}_{21}=78.328$ & $\bar{x}_{22}=79.706$ & $\bar{x}_{2}=74.102$ \\
\hline $\begin{array}{c}\text { Marginal } \\
\text { Average }\end{array}$ & $\bar{x}_{1}=77.500$ & $\bar{x}_{2}=70.703$ & \\
\hline
\end{tabular}

TABLE VI. SUMMARY OF FURTHER TESTS WITH SCHEFFE’ METHOD TABLE STYLES

\begin{tabular}{|c|c|c|c|c|}
\hline $\mathbf{H}_{\mathbf{0}}$ & $\mathbf{H}_{1}$ & $\mathbf{F}$ & $\begin{array}{c}\mathbf{F}_{\text {table }} \\
\alpha=\mathbf{0 . 0 5})\end{array}$ & Decision \\
\hline$\mu_{1}=\mu_{2}{ }^{(a)}$ & $\mu_{1} \neq \mu_{2}$ & 12.698 & 5.286 & $\mathrm{H}_{0}$ is rejected \\
\hline$\mu_{1}=\mu_{2}{ }^{(b)}$ & $\mu_{1} \neq \mu_{2}$ & 5.297 & 5.286 & $\mathrm{H}_{0}$ is rejected \\
\hline$\mu_{11}=\mu_{12}$ & $\mu_{11} \neq \mu_{12}$ & 13.756 & 10.027 & $\mathrm{H}_{0}$ is rejected \\
\hline$\mu_{21}=\mu_{22}$ & $\mu_{21} \neq \mu_{22}$ & 0.107 & 10.027 & $\mathrm{H}_{0}$ is accepted \\
\hline$\mu_{11}=\mu_{21}$ & $\mu_{11} \neq \mu_{21}$ & 0.202 & 10.027 & $\mathrm{H}_{0}$ is accepted \\
\hline$\mu_{12}=\mu_{22}$ & $\mu_{12} \neq \mu_{22}$ & 21.064 & 10.027 & $\mathrm{H}_{0}$ is rejected \\
\hline
\end{tabular}

Based on Table VI, the following information is obtained:

- $\mu_{1}=\mu_{2}{ }^{(a)}$, based on Table VI, it can be seen that $\mathrm{F}>\mathrm{F}_{\text {table }}$ so that $\mathrm{H}_{0}$ is rejected. Then it can be concluded that there is a significant difference between the MPSA of male students and female students. Based on Table V, the marginal mean for male students is 68.500 while for female students it is 79.044 so it can be concluded that the MPSA's male students is lower than female students.

- $\mu_{1}=\mu_{2}{ }^{(b)}$, based on Table VI, it can be seen that $F>F_{\text {table }}$ so that $\mathrm{H}_{0}$ is rejected. Then it can be concluded that there is a significant difference between MPSA of students who get GD learning and students who get STAD learning. Based on Table $\mathrm{V}$, the marginal mean for GD learning is 77.500 while for STAD learning is 70.703 so it can be concluded that the GD learning model provides better MPSA than the STAD learning.

- $\mu_{11}=\mu_{12}$, based on Table VI, it can be seen that $F>F_{\text {table }}$ so that $\mathrm{H}_{0}$ is rejected. Then it can be concluded that there is a significant difference between MPSA of students who get GD learning and STAD learning, for male students. Based on Table $\mathrm{V}$, the mean for male students who acquired guided discovery learning was 76.500 while for STAD learning was 60.500 so it can be concluded that for male students, GD learning models provide higher MPSA than STAD learning.

- $\mu_{21}=\mu_{22}$, based on Table VI, it can be seen that $\mathrm{F}<\mathrm{F}_{\text {table }}$ so that $\mathrm{H}_{0}$ is accepted. Then it can be concluded that there is no significant difference between MPSA of students who have GD learning and STAD learning, for female students. It can be concluded for female students, MPSA with guided discovery learning is as good as STAD learning.

- $\mu_{11}=\mu_{21}$, based on Table VI, it can be seen that $\mathrm{F}<\mathrm{F}_{\text {table }}$ so that $\mathrm{H}_{0}$ is accepted. Then it can be concluded that there is no significant difference between MPSA of male and female students who have GD learning. So that it can be said that in GD learning the MPSA of male students is as good as female students.
- $\mu_{12}=\mu_{22}$, based on Table VI, it can be seen that $\mathrm{F}>\mathrm{F}_{\text {table }}$ so that $\mathrm{H}_{0}$ is rejected. Then it can be concluded that there is a significant difference between the MPSA of male and female students who obtain STAD learning. Based on Table V, in STAD learning mean score of MPSA for male students is 60.500 while for female students is 79.706 so it can be concluded that in STAD learning the MPSA of male students is lower than female students.

\section{Discussion}

The results of the study showed that the mathematical problem solving ability of students who obtained guided discovery learning was higher than students who obtained cooperative learning STAD-type. This is possible because guided discovery learning has several advantages over STADtype cooperative learning.

Based on the steps for each learning models, for guided discovery learning, it begins with the provision of a stimulus/problem. Students will be interested in taking lessons because the problems given are close to their daily lives, then followed by teacher's guidance so students can identify problems, collect information, and process data. After students find a solution to the problem, then verification is carried out with a class presentation that will be compared with the results of other groups and finally students together with teacher will concluded the results to get a generalization of problem solving. And all the steps are also carried out by students in the teamwork, so that each student will exchange information and knowledge that they have to get a solution to the problem. STAD learning begins with the provision of information from the teacher about the material to be studied, followed by group formation, guiding groups in working on tasks, evaluating and giving awards. In this learning students are only active in working on assignments in groups to be able to solve questions or problems related to the learning given. Even though this is easier for students to accept because of the teacher's guidance from the beginning of learning, students are also easier to forget about the concept of material being learned. This is because students are not actively involved in finding concepts, which is different from guided discovery learning which is meaningful learning where knowledge will be embedded for a longer period of time.

With regard to learning theory, guided discovery learning embraced to constructivism theory in which students construct their own knowledge from new information by combining preexisting knowledge. In guided discovery learning, students are given the responsibility to solve difficult tasks or problems but still within the reach of students that is in accordance with Vygostky's theory and there are also social interactions with friends and also help or guidance from the teacher to complete the tasks. The teacher will act as a facilitator to provide assistance/ guidance to students instead of telling, this will improve students' ability to solve problems.

Similar research as in [23] showed that the improvement of mathematical problem solving ability of experimental class students taught by guided discovery was better than the control class taught with conventional learning and there was a significant difference between the ability of the two learning models. The research as in [24] about increasing students' 
mathematical understanding and disposition through guided discovery learning models showed that there was an increasing in mathematical ability among students taught using guided discovery learning higher than students taught by direct learning.

Cooperative learning STAD-type is a learning that involves students working collaboratively to achieve goals. Students work together in study groups and each is responsible for the learning activities of members of the groups so that all group members can master the subject matter well. This learning arises from the concept that students will find it easier to find answers and understand difficult material if they discuss it with each other. Chapin, O'Connor, and Anderson in [25] stated that there are five learning practices that are associated with improving the quality of discussions in the classroom, as follows: (1) talking to involve students in discussions; (2) asking; (3) using student thinking to encourage discussion; (4) preparing a supportive learning environment; and (5) arranging discussions. By working in groups, makes students think critically and creatively also share information to solve problems. This is in line with the opinion. Similar study as in [26] showed that the mathematical problem solving ability of students taught in the cooperative learning STAD-type are higher than traditional learning.

From the result of analysis data, there is an interaction between the learning model and the gender of students towards students' mathematical problem solving ability. The presence of the interaction between gender and students 'learning model on the ability of students' mathematical problem solving means that learning models together with gender make a differences in mathematical problem solving ability of students significantly from both the experimental class. With the influence of interaction, it cannot be concluded directly that one of the learning models is better than the other. For that we need further test of data on students' mathematical problem solving ability.

From the results of further tests it was found that there were significant differences between the mean score of mathematical problem solving ability of the male students of the two learning. This is due to the different learning stages of the two learning models. In guided discovery learning model, students will be interested in the discovery process so that their understanding will last longer, whereas in cooperative learning students rely more on teachers to obtain information so that in solving problems, students will lose their activity. Then it was found that there was no significant difference between the ability to solve female students between the two learning. This is possible because female students pay better attention to the process of finding and learning cooperatively. Furthermore, it was found that there was no difference in the mean of male and female students in guided discovery learning, whereas in STAD learning, it was found that there were differences in the mean of male and female students. This can be caused because female students are more diligent than men. According to Mitsos and Browne in [27], there is evidence that explains that women's achievement levels are better than men. Women have better motivation than men. This certainly will support his learning achievements at school. High ability for male in terms of mathematics, but women are superior in their effective aspects (diligent, thorough, and careful).

\section{CONCLUSION}

Based on the results of the analysis, learning mathematics both with guided discovery learning and cooperative learning STAD-type can be summarized as follows:

1. There is a difference of mathematical problem solving ability between students who taught with guided discovery learning and cooperative learning STAD-type.

2. There is an interaction between learning models and gender on students' mathematical problem solving ability.

\section{ACKNOWLEDGMENT}

This research was supported by my supervisors Prof. Dr. Mukhtar, M.Pd and Dr. Syafari, M.Pd. And the author would like to thank family for their continuous support and encouragement.

\section{REFERENCES}

[1] Abdurrahman, M. 2012. Anak Berkesulitan Belajar: Teori, Diagnosis, dan Remediasinya. Jakarta: Rineka Cipta.

[2] TIMSS. 2016. TIMSS 2015 International Result in Mathematics. Available at http://timss2015.org/.

[3] Organization for Economic Cooperation and Development (OECD) 2016. PISA 2015 Results in Focus. Available at www.oecd.org/pisa.

[4] Fadilah, S. 2009. Kemampuan Pemecahan Masalah Matematis dalam Pembelajaran Matematika. Prosiding Seminar Nasional Penelitian, Pendidikan dan Penerapan MIPA Fakultas MIPA, Universitas Negeri Yogyakarta, pp. 553-558.

[5] National Council of Teachers of Mathematics. 2000. Principles and Standards for School Mathematics. Reston: NCTM.

[6] Depdiknas. 2003. Pengajaran Berdasarkan Masalah. Jakarta: Departemen Pendidikan Nasional.

[7] Napitupulu, E. E. 2008. Mengembangkan Strategi dan Kemampuan Siswa Memecahkan Masalah Matematik. Pythagoras, 2008 (4): 2. DOI: http://dx.doi.org/10.21831/pg.v4i2.557.

[8] Ansari, B.I. 2012. Komunikasi Matematika Konsep dan Aplikasi. Banda Aceh: Yayasan PeNa.

[9] Fitria, A. C.; Sulistyaningsih, D. and Prihaswati, M. 2014. Keefektifan Metode Guided Discovery Learning Bernuansa Multiple Intelligences untuk Meningkatkan Kemampuan Pemecahan Masalah Matematis. JKPM. Vol.1 No.2, pp. 1-6.

[10] Rattanatumma, T. and Puncreobutr, V. 2016. Assesing the Effectiveness of STAD Model and Problem Based Learning in Mathematics Learning Achievement and Problem Solving Ability. Journal of Education and Practice. 7(12): 194-199.

[11] Mellawaty; Trisnawati, T., Ningsih, E. F. and Susilawati, I. 2015. Meningkatkan Kemampuan Berpikir Kreatif Matematis dan SelfRegulated Learning Siswa MTs Ar-Rohmah melalui Model Pembelajaran Discovery Learning. Proceeding of ACER-N Meeting and Seminar, (Online), Vol 1, ISSN: 2407-8867, (http://repository.unpas.ac.id/4025/1/Hestu\%20Wilujeng.pdf, accessed on March 26, 2018).

[12] Tran, T.; Nguyen, N. G., Bui, M. D. and Phan, A. H. 2014. Discovery Learning with the Help of the GeoGebra Dynamic Geometry Software. Vietnam: International Journal of Learning, Teaching and Educational Research Vol. 7, No. 1, pp. 44-57, August 2014.

[13] Dahar, R.W. 2011. Teori-Teori Belajar dan Pembelajaran. Jakarta: Erlangga.

[14] Kuhlthau, C. C. 2007. Guided Inqury: Learning in The $21^{\text {st }}$ Century School. Wesport, CT: Libraries Unlimited. 
[15] Hosnan, M. 2014. Pendekatan Saintifik dam Kontekstual dalam Pembelajaran Abad 21. Bogor: Ghalia Indonedia.

[16] Isjoni. 2009. Pembelajaran Kooperatif. Yogyakarta: Pustaka Pelajar.

[17] Trianto. 2016. Mendesain Model Pembelajaran Inovatif-Progresif: Konsep, Landasan, dan Implementasinya pada Kurikulum Tingkat Satuan Pendidikan (KTSP). Jakarta: Kencana.

[18] Laine, A.; Naveri, L., Pehkonen, E., Ahtee, M. and Hannula, M. S. 2011. Third-graders's Problem Solving Performances and Teacher's Actions. Proceedings from the $13^{\text {th }}$ ProMath Conferences, (Online), (http://umu.diva-portal.org/smash/get/diva2:594205/FULLTEXT01.pdf, accessed on March 26, 2018).

[19] Tan, D.A. 2018. Mathematical Problem Solving Heuristics and Solution Strategies of Senior High School Students. International Journal of English and Education. 7(3): 1-17.

[20] Hasratuddin. 2015. Mengapa Harus Belajar Matematika?. Medan: Perdana Publishing.

[21] Polya, G. 1973. How to Solve It: A New Aspect of Mathematical Method. Princeton, NJ: Princeton University Press.

[22] Rosli, R.; Goldsby, D. and Capraro, M. M. 2013. Assessing Students' Mathematical Problem-Solving and Problem-Posing Skills. Asian Social Science. 9 (16): 54-60

[23] Azizah, D. N. 2016. Penerapan Model Guided Discovery dalam Meningkatkan Kemampuan Problem Posing dan Kemampuan Pemecahan Masalah Matematika serta Dampaknya terhadap Penurunan Kecemasan Matematis Siswa (di SMP IT Anni'mah). Thesis, (Online), http://repository.unpas.ac.id/id/eprint/12350, accessed on March 4, 2019).

[24] Pasaribu, E. Z.; Surya, E. and Syahputra, E. 2016. Peningkatan Kemampuan Pemahaman Matematis Siswa Melalui Model Pembelajaran Penemuan Terbimbing di MTsN 1 Padangsidempuan. Paradikma. 9(2): 11-19.

[25] Mukhtar and Firdaus, M. 2015. Merancang Aktivitas Belajar Matematika untuk Mengembangkan Keterampilan Penalaran Siswa. Prosiding Semirata 2015 bidang MIPA BKS-PTN Barat Universitas Tanjungpura Pontianak. pp: 200-207.

[26] Rumapea, R. 2018. Pengaruh Model Pembelajaran Kooperatif Tipe STAD dan Pemberian Soal Open-Ended terhadap Kemampuan Pemecahan Masalah Matematis Siswa Ditinjau dari Kemampuan Awal Matematika. Jurnal Pendidikan Matematika. 12(1): 1-14.

[27] MZ, A. Z. 2013. Perspektif Gender dalam Pembelajaran Matematika Marwah. 12 (1), $14-31$. 